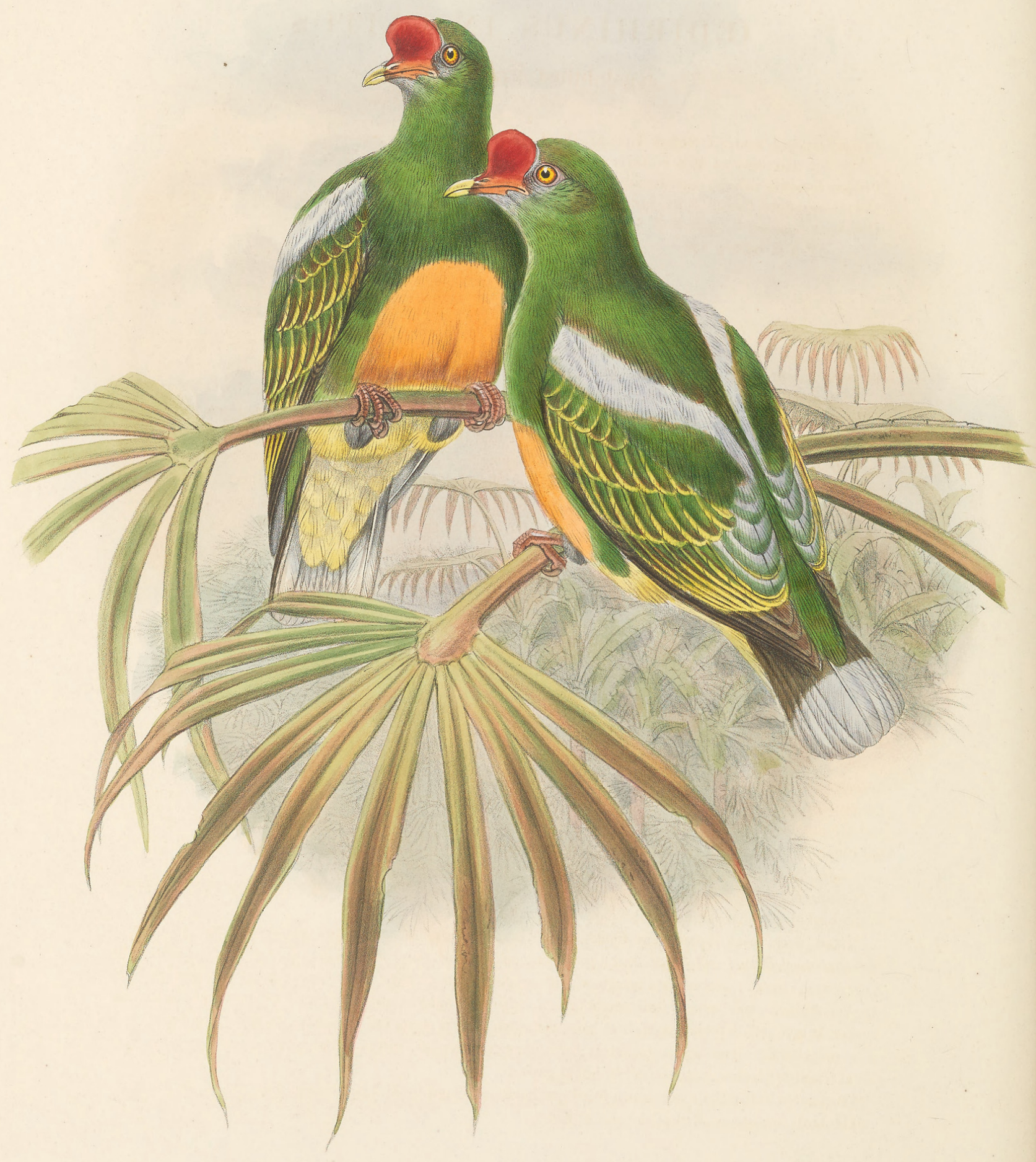

AEDIRHIINUS INS OLYTUS. 


\title{
OEDIRHINUS INSOLITUS.
}

\author{
Knob-billed Fruit-Pigeon.
}

\begin{abstract}
Ptilopus insolitus, Schlegel, Nederl. Tijdschr. Dierk. i. p. 61, pl. iii. fig. 3.-Meyer, Rowley's Orn. Miscell. ii. p. 340.-Salvad. P. Z. S. 1877 , p. 196.-Elliot, P. Z. S. 1878 , p. 549.

Ptilopus humeralis jobiensis (monstrosity), Schlegel, Mus. Pays-Bas, Columbæ, p. 16.

Edirhinus globifer, Cabanis \& Reichenow, Sitz. Gesellsch. naturf. Fr. Berlin, 1876, p. 73.-Iid. J.f. O. 1876, p. 326

Edirhinus insolitus, Sclater, P. Z. S. 1877, p. 110.-Rowley, Orn. Miscellany, ii. p. 338, pl. lxvi.-Sclater, P. Z. S. 1878, p. 290.
\end{abstract}

This remarkable bird, which Mr. Dawson Rowley names the "Strange Pigeon," a title it well deserves, was first made known to science in 1861 by Professor Schlegel, who possessed a single example at Leiden in somewhat damaged condition. The locality was stated to be New Caledonia; but this was probably an error, as our next acquaintance with the species was due to Dr. Huesker, who accompanied the German Transitof-Venus Expedition on board the 'Gazelle,' and procured the bird in New Ireland; and his specimen was named Edirhinus globifer by Drs. Cabanis and Reichenow. Shortly afterwards Dr. Sclater received it from Duke-of-York Island, from Mr. George Brown, and identified the species with one previously described, Ptilopus insolitus of Professor Schlegel, who meanwhile had looked upon the species as a monstrosity of his Ptilopus jobiensis. Dr. Sclater gave a woodcut of the head to show the extraordinary knob at the base of the bill; and this illustration was followed by a beautiful figure in Mr. Rowley's 'Ornithological Miscellany,' with an excellent history of the species contributed by Dr. Meyer. During the present year Dr. Sclater has received a second consignment from Mr. Brown, in which there was a large series of this Fruit-Pigeon; and although there were no labels on the birds, the receipt of nearly twenty specimens seems to show that there is no difference in the colour of the sexes, although a good deal of variation in the size and colour of the knob was observable, the individuals which had this character more largely developed being probably the older males.

I have followed the above-named authors in keeping this bird distinct under the genus EEdirhinus, though Mr. Elliot, in his recent Monograph of the genus Ptilopus, has replaced the species in the latter genus, considering that the knob on the bill is paralleled by the protuberance found in some of the species of Carpophaga, which are not recognized as generically distinct. According to the last-named ornithologist the present bird belongs to the section of the genus Ptilopus in which the breast-feathers are not bifurcate, and the middle of the abdomen is orange. It is nearly allied to $P$. iozonus, $P$. humeralis and $P$. jobiensis, but differs not only in the yellow knob on the forehead, but also by having the shoulders and patch on the back light grey, and the tail bright green, with the apical third ashy grey.

Nothing is known of the habits of this fine species; so I must content myself with adding the description of the bird given by $\mathrm{Mr}$. Elliot in the paper above alluded to.

"Head, neck, back, breast, and flanks bright bronzy green; throat green slightly tinged with grey; abdomen deep orange ; shoulders and a patch on each side of the back, at the edge of the mantle, light grey; wings green; secondaries margined with bright yellow on their outer webs; inner secondaries light grey, margined with green; tail bright green, with the apical third ashy grey; crissum and under tailcoverts bright yelIow; bill greenish at base, yellowish at tip; forehead and base of culmen covered by a bony protuberance large and rounded in form, very couspicuous, and of a red colour; tarsi and feet red. Total length $9 \frac{1}{4}$ inches, wing 5 , tail 3 , bill at gape $\frac{3}{4} . "$

The figures in the Plate are drawn from specimens collected by Mr. Brown and lent me by Dr. Sclater. The birds are represented of the size of life. 


\section{$2 \mathrm{BHL}$ Biodiversity Heritage Library}

Gould, John and Sharpe, Richard Bowdler. 1878. "Édirhinus insolitus, Knob-billed Fruit-Pigeon [PI. 50]." The birds of New Guinea and the adjacent Papuan islands : including many new species recently discovered in Australia 5(VIII), -. https://doi.org/10.5962/p.322894.

View This Item Online: https://www.biodiversitylibrary.org/item/230441

DOI: https://doi.org/10.5962/p.322894

Permalink: https://www.biodiversitylibrary.org/partpdf/322894

\section{Holding Institution}

Smithsonian Libraries

\section{Sponsored by}

Biodiversity Heritage Library

\section{Copyright \& Reuse}

Copyright Status: Public domain. The BHL considers that this work is no longer under copyright protection.

This document was created from content at the Biodiversity Heritage Library, the world's largest open access digital library for biodiversity literature and archives. Visit BHL at https://www.biodiversitylibrary.org. 